\title{
'Give mee a Souldier's Coat': Female Cross-Dressing during the English Civil War
}

\author{
MARK STOYLE \\ University of Southampton
}

\begin{abstract}
This article lifts the veil on the women who dressed as men during the English Civil War and on contemporary reactions towards them. The piece begins by noting that - although it is often claimed that the armies of king and parliament were accompanied by many females who had 'counterfeited their sex' in order to march into the field - those claims rest on a surprisingly slim evidential base. Next, the article considers the ways in which both cross-dressed women and women in quasi-masculine attire were viewed during the half century before the war began - and suggests that attitudes towards such women may sometimes have reflected broader politico-religious attitudes. Finally, the article explores the handful of cases in which the presence of cross-dressed women in the rival armies is genuinely attested to - and asks what these cases reveal about reactions to such women during the conflict itself.
\end{abstract}

'Put mee on [a] man's attire,

Give mee a Souldier's coat,

'I'le make King Charles's foes,

Quickly to change their note!

Cock your match, prim[e] your pan,

Let piercing bullets fly,

I do not care a pin,

Whether I live or dye!'

I

$\mathrm{t}$ is with these splendid words that the anonymous heroine of a seventeenth-century ballad - besieged, alongside her husband, in the royalist garrison of Chester - declares her resolve to 'assume the port of Mars' and to ride out, cross-dressed, at her husband's side in order to

I would like to thank the editor of History and the journal's two anonymous readers for their helpful and perceptive comments on this article. I am also indebted to George Bernard, who read and commented on an earlier draft; to Maria Hayward, who provided me with valuable advice on a number of specific points; and to Sarah Roller, who was kind enough to invite me to give a seminar paper on female cross-dressing during the early Stuart period at the University of Bristol in early 2017. Finally, I would like to express my gratitude to the many students at Southampton who have worked with me on this subject over the years, and from whom I have learnt so much: especially Jennie Cobley, Jane Whitehead, Danielle Eddington, Alice Walsh, Sadie Emery, Leonie Hicks and Georgie Moores. 
break through the encircling parliamentarian forces. 'She took a musquet then', the ballad continues:

And a sword by her side,

In disguise like a man,

Her valour so she tried.

And with her true love she,

March't forth couragiously

And made away with speed,

Quite through the enemy.

Clearly, the woman and her husband had not broken out alone, but had done so at the head of a band of royalist troopers, for the ballad specifically goes on to praise the conduct of 'their souldiers brave and bold', before concluding with the final, uplifting, peroration:

Thus have you heard the news,

Of a most valiant wight,

And of his lady brave,

How stoutly they did fight. ${ }^{1}$

These stirring verses - which, when publically performed, must surely have garnered loud applause from loyal supporters of the crown - provide us with perhaps our most vivid contemporary portrayal of a female crossdresser during the English Civil War of 1642-6. They depict a 'resolute lady', who - warmed by a loyal zeal for her king, as well as by a passionate love for her husband - not only took the decision to 'counterfeit her sex' in order to march into the field, but also went so far as to fight the king's enemies herself, while - physically, at least - at the head of a body of armed men. ${ }^{2}$ Yet all is not quite as it seems, for - like so many of the 'martial maids' who were feted in popular verse during the seventeenth and eighteenth centuries - the ballad's heroine may well have been a largely fictional construct, while the lines in her praise were printed around 1680 - some thirty-five years after the conflict between Charles I and his parliament had come to an end. ${ }^{3}$ The story of the resolute lady of Chester therefore demonstrates particularly well both the intrinsic human interest

${ }^{1}$ British Library, London [hereafter BL], The Valiant Commander with his Resolute Lady (broadside, no place or date of publication), reprinted in J. Woodfall-Ebsworth (ed.), The Roxburghe Ballads, VI (Hertford, 1889), pp. 282-3.

2 Ibid.

${ }^{3}$ For the many popular songs and ballads of this period which describe women donning male attire in order to go to the wars, see D. Dugaw, Warrior Women and Popular Balladry, 1650-1850 (Cambridge, 1989), passim; and R. M. Dekker and L. C. van de Pol, The Tradition of Female Transvestism in Early Modern Europe (Basingstoke, 1989), p. 29. The nineteenth-century editor of The Valiant Commander suggested that the ballad had been composed during the 1640s; see Woodfall-Ebsworth, Roxburghe Ballads, VI, p. 283. The British Library catalogue ascribes the surviving printed copies to the period c. 1678-85, however, and, as Angela McShane-Jones has observed, ballads which alluded to the events of the Civil War 'were mainly written long after the event', see A. McShane-Jones, 'Rime and reason: the political world of the English broadside ballad, 1640-1689', unpublished Ph.D. Thesis, University of Warwick (2004), p. 130. 
and the peculiar elusiveness of the subject of female cross-dressing during the English Civil War.

In recent years, historians of late medieval and early modern England have cast a flood of new light on contemporary attitudes towards female transvestism. ${ }^{4}$ Their work has demonstrated that, although both female and male cross-dressing is explicitly condemned in the Old Testament, historic responses to those practices have been intriguingly diverse. ${ }^{5}$ Ever since the publication of Sandra Clark's classic article 'Hic Mulier, Haec Vir and the controversy over masculine women' in 1985, the fashion for women to adopt a quasi-masculine style of dress during the reign of James I - and the wave of public opprobrium which that fashion eventually provoked - have been the focus of some especially stimulating research. ${ }^{6}$ Rather surprisingly, perhaps, much less has been written about the women who genuinely did dress as men during the Civil War, and about contemporary reactions towards them, while much of what has been written about those two subjects rests on fairly slender evidence?

The most influential modern account remains that which appears in Antonia Fraser's popular history of women in seventeenth-century England, The Weaker Vessel, published in $1984 .{ }^{8}$ Having begun by observing that 'the armies of the Civil Wars... were attended by hordes of female camp followers', Fraser added that 'many of these [women had] adopted male clothing, more for convenience than caprice'. ${ }^{9}$ She then noted some occasions on which women are said to have abandoned conventional feminine attire in order to follow the rival armies into the field or even, occasionally, in order to fight as soldiers themselves. ${ }^{10}$ Fraser's book went on to become a best-seller and, in consequence, her account of female cross-dressing during the Civil War has been very

\footnotetext{
${ }^{4}$ See, for example, D. Cressy, 'Gender trouble and cross-dressing in early modern England', Journal of British Studies, 35 (1996), pp. 438-65; B. Capp, 'Playgoers, players and cross-dressing in early modern London: the Bridewell evidence', The Seventeenth Century, 18/2 (2003), pp. 159-71; F. Easton, 'Gender's two bodies: women warriors, female husbands and plebeian life', Past and Present, 180/1 (2003), pp. 131-74; and J. M. Bennett and S. McSheffrey, 'Early, erotic and alien: women dressed as men in late medieval London', History Workshop Journal [hereafter HWJ], 77/1 (2014), pp. 1-25.

${ }^{5}$ For the biblical prohibition, see Deuteronomy 22.5.

${ }^{6}$ S. Clark, 'Hic mulier, haec vir and the controversy over masculine women', Studies in Philology, 82/2 (1985), pp. 157-83. See also S. Orgel, Impersonations: The Performance of Gender in Shakespeare's England (Cambridge, 1996), pp. 83-4, 109; H. Pierce, Unseemly Pictures: Graphic Satire and Politics in Early Modern England (London, 2008), pp. 5-8; and A. Bayman, 'Cross-dressing and pamphleteering in early seventeenth-century London', in D. Lemmings and C. Walker (eds), Moral Panics, the Media and the Law in Early Modern England (Basingstoke, 2009), pp. 63-77.

7 Neither of the two most important studies of gender in the Civil War-D. Purkiss, Literature, Gender and Politics during the English Civil War (Cambridge, 2005); and A. Hughes, Gender and the English Revolution (Abingdon, 2012) - explore the subject of female cross-dressing.

8 A. Fraser, The Weaker Vessel: Women's Lot in Seventeenth-Century England (London, 1984; 3rd edn, 1987), pp. 220-6.

9 Ibid., p. 220.

10 Ibid., pp. 220-6. For women as soldiers, see also P. Higgins, 'The reactions of women', in B. Manning (ed.), Politics, Religion and the English Civil War (London, 1973), pp. 179-222, at p. 220.
} 
widely read - and cited. ${ }^{11}$ Yet it is not without its flaws. First, Fraser's discussion contains a number of factual errors. ${ }^{12}$ Second, it is as much about the post-conflict period as it is about the Civil War proper. ${ }^{13}$ Third, and perhaps most important of all, Fraser's account conflates women who cross-dressed with women who fought - and, indeed, with women who simply accompanied the armies - and thus has the effect of obscuring just how tantalizingly little we really know about the women who donned male attire during the conflict. The present article will consider the handful of occasions on which the presence of transvestite women in the armies of king and parliament is genuinely attested to in contemporary sources, and will ask what these rare cases reveal about contemporary attitudes towards female cross-dressing. ${ }^{14}$ Because the wartime evidence can only be fully understood within the context of what had gone before, however, the article will begin by surveying some of the ways in which both fully cross-dressed women and women sporting quasi-masculine styles had been viewed during the years which preceded the conflict.

\section{I}

As recent research has shown, there had always been a handful of women who cross-dressed in late medieval London, frequently in order to facilitate illicit sexual liaisons, and during this period the 'ecclesiastical and civic authorities', and presumably the wider public too, had 'understood female cross-dressing within the long established category of women's sexual misrule'. ${ }^{15}$ This had continued to be the case during the half-century before the Civil War, but at the same time a popular fascination with picaresque tales of women who disguised themselves as men in order to go to the wars or to take part in other

\footnotetext{
11 For examples of later writers who have cited - and, in some cases, been heavily influenced - by Fraser's work on this subject, see Dekker and Van de Pol, Female Transvestism, p. 115; Dugaw, Warrior Women, pp. 46, 129, 146; C. Carlton, 'The impact of the fighting', in J. Morrill (ed.), The Impact of the English Civil War (London, 1991), pp. 17-31, at p. 26; C. Carlton, Going to the Wars: The Experience of the British Civil Wars, 1638-51 (London, 1992), pp. 308-9; A. Plowden, Women All on Fire: The Women of the English Civil War (Stroud, 1998), p. xv; J. Barratt, Cavaliers: The Royalist Army at War, 1642-46 (Stroud, 2000), p. 186; and J. Barratt, 'Secrets of the she-soldiers', web article, <http://hwa-galleria.co.uk/features/secrets-of-the-she-souldiers > [accessed 15 Aug. 2015].

12 Fraser claims, for example, that, in 1642, a group of Sir John Byron's royalist soldiers were accompanied by a number of 'whores' who 'counterfeited their sex', but the source which she cites does not bear this out: see Fraser, Weaker Vessel, p. 220; and B. Whitelock, Memorials of the English Affairs, 4 vols (Oxford, 1853), I, p. 188.

13 Fraser devotes a good deal of time to the famous cases of 'Mr Clarke' and Anne Dymoke, for example, who were both reported to have been unmasked as female soldiers during the 1650 s. See Fraser, Weaker Vessel, pp. 222-3 and pp. 225-6; BL, Anon., The Gallant She Souldier (London, c. 1655); and Historical Manuscripts Commission, Report on the Manuscripts of F. W. LeybornePopham (London, 1899), p. 112.

14 For references to women disguised as soldiers serving in the parliamentarian army after 1646, see Fraser, Weaker Vessel, pp. 225-6; and A. Laurence, Women in England, 1500-1760: A Social History (London, 1994), pp. 250-1.

15 Bennett and McSheffrey, 'Early, erotic and alien', passim (quotation, p. 3).
} 
stereotypically 'masculine' activities had also been starting to take hold. ${ }^{16}$ During the 1590s, books, ballads and even a full-blown stage-play had been written about the escapades of 'Long Meg of Westminster', a crossdressing woman who was said to have served in the army of Henry VIII, while towards the end of that same decade, a ballad about a second cross-dressed female soldier, Mary Ambree, had achieved enormous and enduring currency. ${ }^{17}$ During the early 1600 s, moreover, the activities of a contemporary female Londoner with a penchant for male attire, one Mary Frith, had aroused such widespread public interest that her story, too, had been dramatized in a play entitled The Roaring Girle, or Moll Cut Purse. ${ }^{18}$ First performed at the Fortune Theatre in 1607-8 and later printed, the play had enjoyed great success, and for many years afterwards the stereotype of 'the roaring girl', or 'mannish' female roisterer, had remained an instantly familiar one to the capital's play-goers. ${ }^{19}$

It is impossible to tell how far - if at all - the rise of cross-dressed celebrity 'characters' like Long Meg and Mary Ambree may have helped to foster the fashion for feminine dress with a masculine twist which had been adopted by many stylish women in late Elizabethan and early Stuart London. ${ }^{20}$ What is clear is that this fashion had caused James I to feel a deep sense of unease, for in January 1620 the king had famously ordered his clergy to preach 'against the insolencie of our women, and theyre wearing of brode brimd hats [and] pointed dublets [with] theyre haire cut short ... and some of them [carrying] stilettos or poniards [i.e. daggers]'. ${ }^{21}$ Thereafter, a clamorous public conversation about women's supposed propensity for stealing their menfolk's styles had ensued: a conversation which had been vigorously pursued in sermons, in pamphlets, in ballads, in plays and, presumably, in streets and ale-houses right across the capital, and which is today known as the 'man/woman debate'. ${ }^{22}$ Needless to say, almost all of the participants in that debate whose writings have survived were men and - because they generally agreed that for women to wear elements of masculine dress was wrong it is easy to assume that public opinion, or at least male public opinion,

\footnotetext{
${ }^{16}$ On judicial attitudes to cross-dressed women in pre-civil war London, see Capp, 'Playgoers', pp. 165-6; and J. E. Howard, 'Cross-dressing, the theatre and gender struggle in early modern England', Shakespeare Quarterly, 39/4 (1988), pp. 420-1.

17 On Long Meg, see B. Capp, 'Long Meg of Westminster: a mystery solved', in Notes and Queries, 45/3 (1998), pp. 302-4. On Mary Ambree, see Dugaw, Warrior Women, pp. 31-45.

18 On Mary Frith, see P. Griffiths, 'Frith, Mary (1584-1659)', in Oxford Dictionary of National Biography (Oxford, 2004) [hereafter $O D N B],<\mathrm{http} / / /$ www.oxforddnb.com/view/article/ 10189> [accessed 7 Oct. 2017].

19 Clark, 'Hic mulier', p. 161; T. Middleton and T. Dekker, The Roaring Girle: Or Moll Cut-Purse (London, 1611); and, for later references to Moll, see, for example, T. Dekker, A Tragi-Comedy Called Match Mee in London (London, 1631), p. 6.

${ }^{20}$ For comments which hint that one contemporary writer, at least, believed the two things to be connected, see Anon, Hic Mulier: Or, The Man Woman: Being a Medicine to cure the Coltish Disease of the Staggers in the Masculine-Feminines of our Times (London, 1620), sigs. A4v and B3r.

${ }^{21}$ N. E. McClure (ed.), The Letters of John Chamberlain, 2 vols (Philadelphia, PA, 1939),

II, pp. 286-7.

${ }^{22}$ See authorities cited in n. 6 .
} 
was monolithically behind the king. Certainly, this was the impression given by a contemporary balladeer, who, in a series of verses condemning 'man-women', had rejoiced that 'citty and countrey do both deride 'em; And our king, God blesse him, cannot abide 'em'. ${ }^{23}$

The true situation, however, was almost certainly more complicated than the balladeer suggests. It seems highly unlikely that early modern women would have persisted in wearing quasi-masculine fashions if those fashions had been utterly repugnant to the entire male sex, and it is hard to doubt that many men found the style of the female 'gallants' distinctly alluring, even if they were understandably coy about admitting to this in public. ${ }^{24}$ A remarkable story from Norfolk, moreover - one which was told to Sir Nicholas Le Strange by his cousin, Dorothy Gurney, at some point before the Civil War - reveals that it was possible for a man to go beyond covertly admiring quasi-masculine dress styles and openly to defend the proposition that women might, occasionally, wear breeches. The anecdote, as Gurney told it, runs thus:

The Bury [St Edmunds] Ladyes that us[e]d [to go] Hawking and Hunting, were once in a great vaine of wearing Breeches, and some of them being at dinner one day ... there was one Mr Zephory, a very precise and a silenc't Minister... and, discourse being offer[e]d of fashions, he fell upon this and declaimed much against it; [but] Rob Heighem, a Jouviall blade being there ... he undertook to vindicate the Ladyes, and their fashion, as decent, and such as might cover their shame: 'For', sayes he, 'if an Horse throwes them, or by any mischance they gett a fall, had you not better see them in their Breeches then Naked?' ... 'O no, by no meanes!' [replied the minister] 'By my Troth, Parson', sayes Rob Heighem, 'and I commend the[e] for [i]t, for I am of thy mind too!'. ${ }^{25}$

How should this story be read? To paint Rob Heighem as an earnest defender of women's sartorial freedoms would obviously be going too far. Rather, he emerges from the anecdote as an irreverent young man who had seized on the conversation about 'the Bury Ladyes" breeches as a golden opportunity to tease a strait-laced clergyman. It is worth noting, too, that, although Heighem had originally offered to 'vindicate' the women's declared preference for wearing breeches, by the time he delivers his punch-line, he is plainly imagining the discomfited female riders wearing nothing at all. ${ }^{26}$ Even so, there is a clear distinction between Heighem,

\footnotetext{
${ }^{23}$ F. W. Fairholt (ed.), Satirical Songs and Poems on Costume: From the Thirteenth to the Nineteenth Century, Percy Society, 81 (London, 1849), p. 148.

${ }^{24}$ For allusions to women dressed in men's clothes or in quasi-masculine fashions as 'gallants', see Bennett and McSheffrey, 'Early, erotic and alien', p. 9; and W. Prynne, Historiomastix: The Players Scourge, or Actor's Tragaedie (London, 1632), p. 201.

${ }^{25}$ H. F. Lippincott (ed.), Merry Passages and Jeasts: A Manuscript Jestbook of Sir Nicholas Le Strange (1603-1655), Salzburg Studies in English Literature: Elizabethan and Renaissance Studies, 29 (Salzburg, 1974), p. 102.

${ }^{26}$ It is clear that contemporaries were keenly aware of the potential for 'wardrobe malfunction' among female equestrians. For another early Stuart jest about a woman tumbling from a horse and 'showing all that ever God sent her', see P. M. Zall (ed.), A Nest of Ninnies and Other English Jestbooks of the Seventeenth Century (Lincoln, NE, 1970), p. 11.
} 
who is prepared to discuss the idea of women wearing breeches, and even - albeit, perhaps, facetiously - to take the side of individual women who express the wish to do so, and 'Mr Zephory', who, from the moment that this notion is raised, 'declaim[s] much against it'. That Zephory is described as 'a very precise and a silenc't minister' reveals that there is a politico-religious dimension to this story, too, for the word 'precise' was invariably used at the time to refer to 'puritans', or zealous protestants, while the term 'silenced ministers' was usually applied to clergymen who had been ejected from their livings for religious nonconformity. ${ }^{27}$

Gurney's anecdote suggests that a correlation existed - or at least, could sometimes exist - between attitudes towards female cross-dressing and wider cultural and religious attitudes, therefore: with 'jovial blades', like Heighem, regarding such practices as being, at times, admissible, and godly puritans, like Zephory, regarding them as being invariably reprehensible. This means that, while James I's famous pronouncements against women in 'man-like' apparel had clearly reflected his own views on the matter, they had also possessed the potential to win particular applause from those who stood on the puritan wing of the church. ${ }^{28}$ Indeed, as Alastair Bellany has argued in an important article, one of the reasons that James chose to speak out against quasi-masculine fashions in the way that he did might well have been in order to forestall any attempt by his critics - many of whom were themselves puritans - to suggest that these disturbing fashions had been fostered and encouraged at the royal court. $^{29}$

The king's very public intervention would presumably have provided the godly with some reassurance on this point, but following James's death in 1625 and the accession of his son, Charles, anxieties about the activities of cross-dressed women at the top had evidently resurfaced. In 1626, for example, disquiet had been voiced when Henrietta Maria, Charles's French Catholic wife, had not only performed in a play staged at her London residence, Denmark House - this at a time when women actors were barred from the English stage - but had done so alongside a number of her female attendants, who appeared dressed as men. ${ }^{30}$ Two years later,

\footnotetext{
27 See, for example, James I, The Kings Majesties Declaration to his Subjects, Concerning Lawfull Sports to be Used (London, 1618), p. 2, in which James himself referred to 'Puritanes and precise people'; and N. Tyacke, Aspects of English Protestantism, 1530-1700 (Manchester, 2001), p. 65, for the petition presented to James in 1610, in which MPs appealed to him on behalf of the 'deprived and silenced ministers'.

28 McClure, Letters of John Chamberlain, II, p. 294.

29 A. Bellany, 'Mistress Turner's deadly sins: sartorial transgression, court scandal and politics in early Stuart England', Huntington Library Quarterly, 58/2 (1996), pp. 179-210, at p. 205.

30 On the performance of Henrietta and her ladies in the pastoral Artenice in February 1626, see B. Ravelhofer, 'Bureaucrats and courtly cross-dressers in the Shrovetide Masque and the Shepherd's Paradise', English Literary Renaissance, 29/1 (1999), pp. 75-96, at p. 94; M. J. Gough, 'Courtly comediantes: Henrietta Maria and amateur women's stage plays in France and England', in P. A. Brown and P. Parolin (eds), Women Players in England, 1500-1660: Beyond the All-Male Stage (Aldershot, 2005), pp. 193-215, at pp. 206-7; and K. Britland, Drama at the Courts of Queen Henrietta Maria (Cambridge, 2006), ch. 2, passim.
} 
the puritan controversialist William Prynne had published his incendiary pamphlet The Unloveliness of Lovelockes, in which he excoriated:

these ... unnaturall and unmanly times; wherein ... sundry of our Mannish, Impudent...Female sexe, are Hermaphrodited and transformed into men ... not onely in their immodest ... and audacious carriage ... but even in the ... odious, if not whorish, cutting of their haire. ${ }^{31}$

That Prynne was bold enough to observe that such practices were now 'the very manner and Courtship of the times' would have made it easy for his readers to deduce from where he believed these 'degenerous' styles to have emanated. ${ }^{32}$ That he went on to assert that the humiliating series of foreign policy reverses which England had recently suffered should be regarded as divine punishment for permitting such 'monstrous ... fashions' to flourish, moreover, may well have given at least some of those readers pause for thought. ${ }^{33}$

It would be easy to dismiss Prynne as an isolated fanatic - as one '[who] bayes at the moone', as an exasperated privy councillor was later to put it - but there were clearly others who believed that female cross-dressing was regarded with dangerous insouciance in courtly circles. ${ }^{34}$ In April 1628, for example, Walter Yonge of Colyton in Devon, a puritan JP, had noted in his private journal that 'there was a woman apprehended at Plymouth in the habit of a man, by the mayor of Plymouth, at the time the Lord Denbigh and Sir Henry Martin went to sea'. ${ }^{35}$ William Feilding, 1st Earl of Denbigh was the brother-in-law of Charles's favourite, the duke of Buckingham. ${ }^{36} \mathrm{He}$ had travelled to Plymouth in order to take command of the naval force which was preparing to embark on the latest, desperate, attempt to relieve the Huguenots of La Rochelle, then under siege by the French king, and one would hardly have expected the town governors to have placed obstacles in his way. ${ }^{37}$ But Plymouth was a strongly puritan town, and, once the presence of the cross-dressed woman - said to be Martin's mistress - had been discovered in Denbigh's entourage, the local governors had clearly not been prepared to overlook the matter. ${ }^{38}$ 'About the apprehension of ... [this woman] was a great quarrel between Sir Henry Martin's men and some of the town', Yonge went on to observe, 'of which it is reported the mayor will complain to the Parliament'. ${ }^{39}$

31 W. Prynne, The Unloveliness of Lovelockes (London, 1628), preface, sig. A3 recto.

32 Ibid. (my italics).

33 Ibid., sigs A3 verso and A4 recto.

34 S. R. Gardiner (ed.), Documents Relating to the Proceedings against William Prynne, Camden Society, n.s., 18 (1877), p. 25.

35 G. Roberts (ed.), Diary of Walter Yonge, Esquire, Camden Society, First Series, 41 (1848), p. 113.

36 On Denbigh, see A. Thrush, 'Feilding, William, first earl of Denbigh (1587-1643)', in $O D N B$, $<$ http://www.oxforddnb.com/view/article/9251 > [accessed 7 Oct. 2017].

${ }^{37}$ M. Wolffe, Gentry Leaders in Peace and War: The Gentry Governors of Devon in the Early Seventeenth Century (Exeter, 1997), pp. 125-7.

38 On the strength of puritanism in Plymouth, see M. Stoyle, Loyalty and Locality: Popular Allegiance in Devon during the English Civil War (Exeter, 1994), pp. 196-7. For the claim that the cross-dressed woman was Martin's mistress, see BL, Add MSS 35,331 (Diary of Walter Yonge, 1627-41), fo. 16.

39 Roberts, Diary of Walter Yonge, p. 113. 
This last comment is especially significant, because it suggests that Yonge viewed the woman's arrest within a national as well as a local context, and was looking on with keen interest as the godly town councillors of Plymouth reportedly threatened to appeal to the parliament to assist them in punishing the sartorial transgressions which had been countenanced by one of the king's military commanders. It does not seem too far-fetched to suggest that both Yonge and the mayor of Plymouth might well have shared Prynne's view that English arms were unlikely to enjoy God's favour for as long as such 'abuses' were tolerated, moreover.

Following the commencement of the Personal Rule, it had no longer been possible for local magistrates to threaten to report incidents of unpunished sartorial transgression to parliament. Prynne had remained determined to speak out upon such matters, however, and in 1632 he had published his infamous work, Histriomastix in which he had not only lashed women who had the audacity to adopt quasi-masculine styles - 'our man-women English Gallants', as he termed them - but had also castigated the 'women-Actors' of antiquity, all of whom, he thundered, 'were...notorious, impudent, prostituted strumpets'. ${ }^{40}$ As Henrietta Maria had already performed in at least one play, and was even now preparing to take part in another, Prynne can hardly have been surprised by the official wrath which the publication of Histriomastix brought down around his head. ${ }^{41}$ There had been many who had sympathized with Prynne in his subsequent judicial travails, though, and who had regarded him as a martyr. ${ }^{42}$ And after the Personal Rule had collapsed, a parliament had been summoned and Charles I had finally abandoned London to his godly enemies, in 1642, Prynne may be said to have had the last laugh, when the MPs - fearing public disorder in the capital - had ordered that all stage-plays should cease. ${ }^{43}$ There were to be no more cross-dressed male actors at the Fortune, then, and no more women-actors at Denmark House. A number of cross-dressed female players were to perform in the martial tragedy which was about to be enacted across the kingdom as a whole, however, and it is to a consideration of these women - and of the wider ripples that their activities caused - that this article will now turn.

\section{II}

Scrutiny of many hundreds of original manuscripts and printed works has so far yielded just five contemporary references to the presence of crossdressed women in the armies of king and parliament between 1642 and

\footnotetext{
40 Prynne, Histriomastix, pp. 201 and 214.

41 For Henrietta Maria's second pastoral, The Shepherds' Paradise, and for the lengthy rehearsals which preceded it, see Britland, Drama, ch. 6, passim; and Gough, 'Courtly comediantes', p. 209.

42 See W. Lamont, Marginal Prynne, 1600-69 (London, 1963), pp. 4, 28.

43 C. H. Firth and R. S. Rait (eds), Acts and Ordinances of the Interregnum, I (London, 1911), pp. $26-7$.
} 
1646 (though more doubtless remain to be found). ${ }^{44}$ In statistical terms, of course, this is an infinitesimal figure, and it might well be objected that it is impossible to base any firm conclusions upon such meagre scraps of evidence. Yet, when it comes to the subject of female cross-dressing during the English Civil War, meagre scraps of evidence are all that we have. Bella Mirabella has recently observed that anyone wishing to recover the history of the female hucksters who helped their male partners to sell quack medicines in early modern Europe must scour the primary sources for what Mirabella terms 'the flicker: the brief mention of the female performer, added, often as an aside, by the male writers of the day, who do not present her as a primary player, and who often do not even mention her name' ${ }^{45}$ Anyone wishing to recover the history of the female crossdressers of the Civil War must proceed in precisely the same way - and while the collection of fleeting glimpses of women in male attire which are interrogated in the following pages obviously cannot hope to provide a comprehensive picture of such women's experiences between 1642 and 1646 , they can, at least, provide some preliminary indications of what these women did and of how they were viewed.

The earliest reference to have been found so far appears in a letter sent by an anonymous writer in Charles I's camp to a friend in July 1642: a letter which was subsequently published in a pro-royalist newspamphlet. ${ }^{46}$ The relevant passage was touched on in Fraser's book, but not cited by her at length, so what, precisely, does it say? The author begins by remarking that 'a Trage-Comique passage [recently] happened [which is] incident to Captains', and then goes on to relate how 'a poore loving Wench ... [named] Nan Ball ... was taken in mans cloathes, waiting upon her beloved Lieutenant' in the king's fledgling army near York, 'and by a foolish accident [was] betrayed and carried before the Earle of Lindsey'. ${ }^{47}$ Fraser assumes that Lindsey was the lieutenant's regimental commander, but as he was not only an infantry colonel but was also Charles I's Lord Chamberlain - and, by virtue of that great household office, was even then 'giv[ing] all ... directions to the [royal] army' during the king's temporary absence at Leicester - it seems far more likely that he investigated the affair in his latter, much more elevated, capacity. ${ }^{48}$ Whatever the case,

\footnotetext{
${ }^{44}$ I have not included in this figure either the royalist 'woman corporall' reported to have been captured at Shelford Church in Nottinghamshire in late 1645 - who may, or may not, have been a female cross-dresser - or 'Jane Ingleby', the woman who is sometimes said to have fought for the king at Marston Moor, but for whose supposed wartime activities I can find no contemporary evidence, see E.308 [30], Anon., A Catalogue of the Names of the new Lords created by the King (10 Nov. 1645), p. 7; P. Young, Marston Moor 1644: The Campaign and the Battle (Kineton, 1970; rev. edn Moretonin-Marsh, 1997), p. 149; and Fraser, Weaker Vessel, p. 221.

${ }^{45}$ B. Mirabella, 'Quacking Delilahs: female mountebankes in early modern England and Italy', in Brown and Parolin, Women Players in England, pp. 89-105, at p. 89.

${ }^{46}$ E.202 (21), A Diurnall and Particular of the Last Weekes daily Occurents from his Majesty (London, 16-26 July 1642).

${ }^{47}$ Fraser, Weaker Vessel, p. 221; and E.202 (21), p. 6.

${ }^{48}$ Fraser, Weaker Vessel, p. 221; P. R. Newman, Royalist Officers in England and Wales: A Biographical Dictionary (London, 1981), p. 27; and E.202 (21), pp. 5-6.
} 
Lindsey clearly took a dim view of the lovers' conduct. The lieutenant 'was quit from his command', the letter-writer goes on, while his crossdressed consort 'should have suffered publique shame' - by which either a whipping or a pillorying is probably meant - 'but', in the end, the correspondent concludes, 'a letter was procured from the Duke of Yorke [i.e. Charles I's nine-year old son, James] for her reprieve, and so, loving heart, she was turn'd [away] to seek her fortune' ${ }^{49}$

What should we make of this story, and of the way in which it is told? Perhaps the first thing to note is that, by terming the affair 'a Trage-Comique passage', the letter-writer may well have been making a playful allusion to William Cartwright's stage-play, The Lady Errant, first performed during the 1630s. ${ }^{50}$ Subtitled 'A Tragi-Comedy', Cartwright's drama had included a female warrior named Machessa - the titular 'lady errant' - among its leading characters, so it is easy to see why this particular play might have leapt to the letter-writer's mind when he first heard of the cross-dressed woman's discovery. ${ }^{51}$ That he should immediately have reached for a theatrical parallel is revealing in itself, of course, as it well illustrates the contemporary tendency to associate transvestism with the world of the stage. ${ }^{52} \mathrm{~A}$ tendency to think of specifically female transvestism in this context may well have been especially marked among those who had frequented the theatres of England during the Personal Rule, moreover, for that period had seen the performance of a number of plays in which cross-dressed female characters (albeit played by male actors) had taken a central role. ${ }^{53}$

The second interesting thing about the anecdote is that it initially appears to suggest that official royalist attitudes towards female crossdressing were sternly disapproving: a point which is underlined by the

\footnotetext{
49 E.202 (21), p. 6. For the judicial whipping of cross-dressed women before the Civil War, see Howard, 'Cross-dressing', p. 421; Capp, 'Playgoers', pp. 165-6; and Laurence, Women in England, p. 252. For the pillorying and parading of women in public for the same offence, see Bennett and McSheffrey, 'Early, erotic and alien', pp. 21-3; and Howard, 'Cross-dressing', p. 420.

${ }^{50}$ On Cartwright himself and the date of his play's first performance, see D. Flynn, 'Cartwright, William (1611-1643)', in $O D N B,<\mathrm{http} / / / \mathrm{www}$. oxforddnb.com/view/article/4823> [accessed 7 Oct. 2017]. The play was eventually published during the Interregnum, see W. Cartwright, The LadyErrant: A Tragi-Comedy (London, 1651). For three helpful discussions of the play, see S. Tomlinson, 'She that plays the king: Henrietta Maria and the threat of the actress in Caroline culture', in G. McMullan and J. Hope (eds), The Politics of Tragicomedy: Shakespeare and After (London, 1992), pp. 199-201; J. Farnsworth, 'Defending the king in Cartwright's "The Lady Errant", Studies in English Literature, 1500-1900, 42/2 (2002), pp. 381-98; and S. Tomlinson, Women on Stage in Stuart Drama (Cambridge, 2005), pp. 106-13.

51 The term 'lady errant' was sometimes used by contemporaries as shorthand for a female warrior; see, for example, S. Shepherd, Amazons and Warrior Women: Varieties of Feminism in SeventeenthCentury Drama (Brighton, 1981), p. 66.

${ }_{52}$ On the perceived connection between cross-dressed women (and men) and the world of the theatre, see Cressy, 'Gender trouble', pp. 444, 462; Capp, 'Playgoers', p. 168; and Bayman, 'Crossdressing', p. 67.

${ }^{53}$ See, for example, T. Randolph, The Jealous Lovers: A Comedie Presented to their Gracious Majesties at Cambridge (Cambridge, 1632); and R. Chamberlaine, The Swaggering Damsell: A Comedy (London, 1640). For the argument that there was 'a seismic shift' in female representations on the stage during the late 1620s and 1630s, see J. Sanders, Caroline Drama: The Plays of Massinger, Ford, Shirley and Brome (Plymouth, 1999), ch. 3 (quotation at p. 41).
} 
fact that Ball was brought before the second most senior figure in the royalist camp to answer for her transgressive behaviour. Yet there is a paradox here, for the harshness of the sentence which Lindsey originally pronounced upon Ball was at once undercut by his willingness to remit the most unpleasant part of her punishment, and to content himself with merely expelling her from the camp instead. The explanation for this may well be very simple. At the time that Ball and her lover were brought before Lindsey, no official regulations had yet been drawn up to govern the conduct of the royalist army. ${ }^{54}$ When deciding how to deal with their case, therefore, the earl would probably have turned to the two sets of 'ordinances of war' which had been drawn up to regulate the behaviour of Charles's armies during the Bishops' Wars of 1639 and 1640. ${ }^{55}$ Neither of these documents has anything to say about cross-dressed women, but one of them includes the stipulation that any 'suspicious and common women' who were discovered in the army were to be turned away, while any officer found in the company of such a woman was to lose his place. It was only women discovered in the army for a second time who were to be 'whipped like common strumpets'. ${ }^{56}$ So the judgements which Lindsey passed on the two lovers appear to have been precisely according to the book.

Why, then, did the letter-writer state that Ball had originally been sentenced to undergo a harsher punishment? We will probably never know, but it is possible that, when the case first came before Lindsey, he had felt that Ball's cross-dressing had aggravated her offence, and had therefore directed that she should be physically punished - only to relent after he had received the Duke of York's letter. In any case, it seems highly unlikely that the infant duke would have intervened on Ball's behalf on his own initiative. Instead, he had surely acted at the prompting of other senior royalists, who were keen, for whatever reason, to see let Ball off the hook. And that Lindsey's eventual decision to temper justice with mercy was welcomed by many in the royalist camp is strongly suggested by the tone of the anonymous letter-writer's account - which is consistently sympathetic towards the 'poore wench' with the 'loving heart' who had followed her sweetheart off to war. ${ }^{57}$

The first cross-dressed woman who is known to have come to the attention of the king's commanders appears to have been treated with relative leniency, then, and to have been regarded with sympathy by at least some in the royalist ranks, while the story of her discovery - and,

\footnotetext{
${ }^{54}$ The first ordinances of war drawn up specifically to govern the conduct of the royalist army were issued on 28 Aug. 1642; see M. Griffin, Regulating Religion and Morality in the King's Armies, 16391646 (Leiden, 2004), p. 104; and Military Orders and Articles Established by His Majestie for the better Ordering and Government of his Army (York, 1642).

${ }_{55}$ Lawes and Ordinances of Warre: For the better Government of His Majesties Army Royall (Newcastle, 1639); and Lawes and Ordinances of Warre, Established for the better conduct of the Service in the Northern Parts (London, 1640).

56 Lawes and Ordinances of Warre (1639), p. 5.

57 E.202 (21), p. 6.
} 
more significantly, of her subsequent reprieve from 'public shame' was cheerfully reproduced by the editor of one of the first royalist newspamphlets. ${ }^{58}$ It is conceivable that Ball's example may have emboldened other women to disguise themselves as men in order to follow their lovers into the king's army - or, indeed, to enrol themselves beneath the royal banner for quite different reasons - but, if this was indeed the case, we have no evidence to prove it. What we do know, is that, from the moment the conflict began, Charles I's army was accompanied by an indeterminate number of female camp-followers, who, like the thousands of 'camp-women' who accompanied armies elsewhere in Europe at this time, may be presumed to have included, first, wives; second, 'whores' (the harsh term used to refer to the unmarried partners of individual soldiers); and, third, other, often unattached, women who provided a variety of personal services to the troops. ${ }^{59}$ Among the women in the king's train at the beginning of the war was Dorothy Leeke: a young gentlewoman who had found herself swept up into the field after Sir Edward Sydenham had joined Charles at York, and his wife, Lady Sydenham - upon whom Leeke was then attending - had resolved to follow her husband into the royal army. ${ }^{60}$

Writing to a correspondent from the king's camp at Nottingham on 1 September 1642 - in what is one of the very few original letters from a female Civil War camp-follower to have survived - Leeke made it plain that, even for a woman of her elevated social status, life in the field was hard and uncertain. ${ }^{61}$ 'I think non in moore dainger then myself and our company', she anxiously observed, at one point, 'for if we lous the day [in other words, if the king's forces were defeated in battle by the parliamentarians], what will become of us [i.e. the royalist camp-followers] I know not'. 'We do not louk for any faver of the other side', Leeke continued, with grim prescience, adding that 'I do not love to think of it [i.e. a potential royalist defeat], and I trust I shall not live to see it.' 'Part of our trouble now', Leeke went on, turning to more quotidian matters, 'is that the wether grows could and it will be ill traviling, and we have those thinges which should have kept us warme at Yorke - but by that time we have folloed the camp another yeare', she added, resolutely, 'we shall have more witt'. ${ }^{62}$

\footnotetext{
58 These attitudes surely reflected the fact that, as Anna Bayman observes, cross-dressed female characters on the London stage had 'usually [been] portrayed with a great deal of sympathy' during the years before the Civil War. See Bayman, 'Cross-dressing', p. 70.

${ }^{59}$ For royalist female camp-followers during the Civil War, see M. Stoyle, Soldiers and Strangers: An Ethnic History of the English Civil War (London, 2005), pp. 28-9, 54-5, 60, 67-9, 139-42, 163, 183; and M. Stoyle, 'The road to Farndon Field: explaining the massacre of the royalist women at Naseby', English Historical Review, 123/503 (2008), pp. 895-923. For female camp-followers in early modern Europe, see J. A. Lynn, Women, Armies and Warfare in Early Modern Europe (Cambridge, 2008), passim.

60 BL, M/636 (Microfilms of the Verney Papers), Reel 4, Dorothy Leeke to Lady Verney, 1 Sept. 1642. For Leeke's antecedents, see F. P. Verney (ed.), Memoirs of the Verney Family during the Seventeenth Century, I (London, 1907), p. 118.

${ }^{61} \mathrm{BL}, \mathrm{M} / 636$, Reel 4, Leeke to Verney, 1 Sept. 1642.

62 Ibid.
} 
Leeke's final comment suggests that, after two weeks' experience of life in the field, she was already preparing to put her peace-time wardrobe on a war-time footing. For a gentlewoman like Leeke - who would almost certainly have followed the army in the comfort of a coach, or at the very least in a wagon, rather than trudging along on foot with the common herd - the necessary adjustments might well have consisted of little more than stocking-up on furs and warmer clothes. ${ }^{63}$ For many of the more humble royalist camp-women, however, it would have made good sense to have adapted themselves to their new, peripatetic, way of life by casting off their elegant, but restrictive, dresses and pulling on plain but practical breeches. These could well have been teamed with 'soldiers' coats' of the type supposedly worn by the 'resolute lady' of Chester, which were certainly the standard attire of later generations of English female campfollowers ${ }^{64}$ Yet as we have seen, cross-dressing was explicitly condemned by the Bible - and Charles I was an unusually pious monarch. ${ }^{65}$

In June 1643 the king himself made the second allusion to crossdressing in Civil War armies which has so far been traced, when, at the end of a draft proclamation setting out how the forces under his command should behave - a document which the king may well have dictated and which had obviously been presented to him so that he could read and revise it, as was his wont - Charles added several 'apostils', or amendments, in which he indicated matter that he wished to be added to the original text. ${ }^{66}$ Among these royal apostils was a terse statement which ran: 'Memorandum: that no woman presume to weare mans apparell under paine of the severest punishment'. This statement was later crossed out, but not because the king had thought better of adding a specific injunction against female cross-dressing in his army to the draft proclamation. Rather, Charles had evidently decided to phrase his amendment more forcefully still and to lay particular emphasis upon it, because, immediately beneath the excised words, the king, or at least his clerk, drew a little hand in the margin of the paper which pointed to the following words:

\footnotetext{
${ }^{63}$ For the subsequent testimony of a hostile parliamentarian writer that the 'gentiler sort' of women accompanying the king's army travelled in coaches; that 'the middle sort of Ammunition Whores' rode in 'waggons'; and that 'the common rabble [went] on foot', see E.288 (28), A More Exact.

Relation of the Late Victory (London, 17 June 1645), p. 4. Camp-women were divided into similar 'classes' in contemporary Continental armies; see J. Turner, Pallas Armata (London, 1683), pp. 276-7. ${ }^{64}$ For the wearing of 'martial coats' by female camp-followers after 1660, see Lynn, Women, Armies and Warfare, p. 47.

${ }^{65}$ For the 'moral earnestness with which ... [Charles] approached his religion' and the 'chastity and decorum he sought to infuse into his family and household', see R. Cust, Charles I: A Political Life (Harlow, 2005), pp. 14, 17.

${ }^{66}$ BL, Harleian MS, 6804 (Papers of the Royalist Council of War), fos 75-6. For a convincing argument that the final version of this proclamation very closely reflected the views of Charles himself, see Griffin, Regulating Religion and Morality, pp. 129-41. For Charles's 'regular practice of apostiling ... letters' to his secretary of state 'and returning them to him for correction', see S. Poynting, " "From his Majestie to me with his awin hand": the king's correspondence during the period of personal rule', in I. Atherton and J. Sanders (eds), The 1630s: Interdisciplinary Essays on Culture and Politics in the Caroline Era (Manchester, 2006), pp. 74-91, at p. 75.
} 
Lastly, because the confounding of habites appertaining to both sexes ... is a thing which Nature and religion forbid, and our soule abhors... [\&] yet the prostitute impudency of some women ... have ... thus conversed in our Army, therefore lett no woman presume to counterfeit her sex by wearing mans apparall under payne of the severest punishment. ${ }^{67}$

These words are fascinating; first, because they suggest that the king believed female cross-dressing to be relatively widespread in his army; second, because they suggest that he intended to take a harder line on that practice than Lindsey had done during the previous year; and third, because - by referring to the 'prostitute impudency' of the royalist camp-women - the king made it plain that he, like so many of his contemporaries, equated cross-dressed women with whores. ${ }^{68}$ Anyone who might have suspected Charles of being more relaxed about 'mannish' fashions than James I had been, then, or who might have interpreted the Duke of York's intervention in the case of Nan Ball as a signal that the king himself was prepared to take a relatively tolerant attitude towards cross-dressed women in the royalist camp would clearly have been quite wrong. On the contrary, Charles's words show that, in his attitude towards women in masculine attire - as in his attitude towards so much else - he was very much his father's son. ${ }^{69}$ Indeed, the outraged tone of Charles's concluding words - words which would have been music to the vestigial ears of William Prynne - suggests that, on this particular subject, the king may well have felt even more strongly than his father had done before him. If there was a current of Cavalier thought which regarded cross-dressed women with equanimity, or even with frank admiration, therefore, it was one which Charles himself utterly repudiated.

On 13 June 1643 the final version of the proclamation - now entitled 'A Proclamation for the Inhibiting all manner of Oathes ... and prophanations by any of his Majesties Army' - was issued in the king's wartime capital of Oxford. ${ }^{70}$ Yet, surprisingly enough, it contained no reference to cross-dressed women - an omission which, as Ian Roy has well observed, is 'curious'. ${ }^{71}$ Why should the king have decided to dispense with the strictures against cross-dressed female camp-followers which he had been so keen to insert into the original text? Three possible

\footnotetext{
$67 \mathrm{BL}$, Harleian MS, 6804, fo. 76. The use of the royal voice or pronoun in the passage makes it almost certain that these were Charles's own words.

68 For the contemporary association of cross-dressed women with sexual misrule and prostitution, see Howard, 'Cross-dressing', pp. 420-1, 424, 437; Cressy, 'Gender Trouble', pp. 444, 460; L. Gowing, 'Gender and the language of insult in early modern London', HWJ, 35/1 (1993), pp. 10-11; Capp, 'Playgoers', pp. 166-8; and Bennett and McSheffrey, 'Early, erotic and alien', pp. 2-3, 20-4.

${ }^{69}$ See K. Sharpe, 'Private conscience and public duty in the writings of Charles I', The Historical Journal, 40/3 (1997), pp. 644-7, 654

${ }^{70}$ See J. F. Larkin (ed.), Stuart Royal Proclamations, II: Royal Proclamations of King Charles I, 1625-46 (Oxford, 1983), pp. 909-10; E. J. Parsons (ed.), 'Some proclamations of Charles I', Bodleian Quarterly Record, 8, suppl. (1936), pp. 16-17; and E.56 (11), Mercurius Aulicus (Oxford, 11-24 June 1643), p. 316

${ }^{71}$ See I. Roy, 'Royalist reputations: the cavalier ideal and the reality', in J. McElligott and D. L. Smith (eds), Royalists and Royalism during the English Civil Wars (Cambridge, 2007), p. 107.
} 
answers present themselves. First, the king's military commanders may have informed him that the habit of donning masculine attire was so commonplace among the women who accompanied his army and so important to those women in terms of their day-to-day mobility not only while on the march, but also while undertaking the foraging trips which helped to keep the royal army supplied with provisions that it was simply not practicable to outlaw the practice. ${ }^{72}$ Second, Charles's advisers may have pointed out to their royal master that for him to admit - in a formal proclamation - that some of the women who accompanied his soldiers were accustomed to cross-dress would only be to invite the derision of enemy propagandists, who had already demonstrated on numerous occasions - in the partisan pamphlets that spewed from the London presses each week - that they were only too ready to highlight and denounce any hint of 'gender confusion' in their opponents' ranks. Third - and closely related to this latter point - Charles may have had second thoughts about incorporating a stern condemnation of female cross-dressing into his proclamation when he recalled that, just three years earlier, his own queen, Henrietta Maria, together with her 'martiall ladies', had appeared on stage dressed in 'Amazonian habits' in the court masque Salmacida Spolia. ${ }^{73}$

'Amazonian habits' should not be equated with full-blown male attire, of course, but, by donning the clothes and weapons of 'warrior women', Henrietta and her ladies might nevertheless have prompted some to feel that the women who were closest to Charles I were also coming perilously close to violating established gender-norms. ${ }^{74}$ To have issued a public condemnation of female cross-dressing in the royalist army, therefore - a condemnation which would at once have presented the London pamphleteers with a golden opportunity to dilate at length upon Henrietta's appearance in pre-war dramatic productions featuring 'martiall ladies' and cross-dressed female players - might well have struck the king's advisers as unwise. The fact that, even as the proclamation was being drafted, Henrietta herself was with a royalist army at York, moreover, would surely have caused those around the king to shrink still further from the notion of raising the subject of 'unnatural' royalist women in a public document, lest it be exploited by their enemies to

\footnotetext{
${ }^{72}$ For the vital role which foraging camp-women played in supplying continental armies, see Lynn, Women, Armies and Warfare, pp. 145-50; and, for a contemporary statement which strongly suggests that royalist camp-women played a similar role, see R. Webb (ed.), Historical Notices . . By Nehemiah Wallington, 2 vols (London, 1869), II, p. 252.

${ }_{73}$ W. Davenant, Salmacida Spolia: A Masque Presented by the King and Queen's Majesties at Whitehall (London, 1640), sig. D2r. For evidence of several other 'Amazonian entertainment[s]' which Henrietta had sponsored since her arrival in England, see Britland, Drama, pp. 65, 165.

74 Admittedly, Charles's mother and her ladies had appeared as warrior queens in The Masque of Queens, staged in 1609, so this was hardly a radical innovation. But, as has been well pointed out, in that masque, too, 'the martial and Amazonian traits' of the female performers could easily have been regarded by some as 'overt expression[s] of feminine nonconformity'; see C. McManus, Women on the Renaissance Stage: Anna of Denmark and Female Masquing in the Stuart Court, 1590-1619 (Manchester, 2002), p. 131.
} 
draw all sorts of painful parallels with the 'mannish' behaviour of Charles I's own queen.$^{75}$ In the king's mind, there was clearly a world of difference between his own wife and her high-born ladies donning 'Amazonian habits' in order to appear in a court masque and his common soldiers' female consorts donning 'men's apparel' in order to move about more freely on campaign, but - as Charles's advisers may well have realized from a zealously puritan perspective, that distinction would have appeared somewhat artificial. ${ }^{76}$ And - if the king's advisers did fear that their enemies might soon start to use the royalists' supposed toleration of at least some forms of female cross-dressing as a stick with which to beat them, then they were quite right to do so, as the next part of this article will make plain.

\section{III}

On 26 June 1643 the MPs assembled at Westminster were treated to a lip-smacking account by John Dod, a minister who had recently passed through the king's quarters in Oxford, of the one 'hundred whores' who, he declared, were maintained by Prince Rupert of the Rhine: Charles's nephew and the commander of the royalist cavalry. ${ }^{77}$ Prominent among these licentious women, Dod went on to allege, were "two of them in boyes apparell who constantly attended [on the prince]' ${ }^{78}$ It is hard to know what to make of Dod's lurid claims. Quite possibly, he had simply invented the entire story. Alternatively, he may have seen some of the women who accompanied Rupert's forces and jumped to the conclusion that they were all prostitutes. ${ }^{79}$ It is even conceivable that Dod had genuinely glimpsed women in Rupert's entourage who were either wholly or partially crossdressed; a contemporary reference to the prince being spotted at Oxford in the company of 'a lady' who wore 'a round black velvett cap' with 'a long white feather with a red tipp at the end of it', and who 'went with her arme akimboe, like a commander' certainly suggests that some of the prince's female friends had a penchant for martial fashions. ${ }^{80}$ What is crystal clear is that Dod's assertion that two women in boys' clothes 'constantly attended' on Prince Rupert was nicely calculated to convey the impression that the king's half-German nephew was a slave to 'unnatural', 'foreign' lusts - for, as English folk were well aware, in Italy, 'courtesans' routinely wore male clothing in order to titillate their clients. ${ }^{81}$

\footnotetext{
75 For Henrietta's presence at York at this time, see M. A. E. Green (ed.), Letters of Queen Henrietta Maria (London, 1857), p. 219.

${ }^{76}$ As Alastair Bellany observes, 'godly commentators tended to collapse traditional distinctions of rank when confronted with the threat of sin'; see Bellany, 'Mistress Turner's deadly sins', p. 207.

77 For Dod, see Journal of the House of Commons [hereafter JHC], III (1643-4), p. 144.

78 BL, Harleian MSS, 164 (Sir Simonds D'Ewes's journal, 1641-43), fo. 233.

${ }^{79}$ For a printed parliamentarian news-report of two months before, which had specifically stated that the women who accompanied Prince Rupert's dragoons were 'whoores', see E. 96 (2), Speciall Passages and Certain Informations (London, 4-11 April 1643), pp. 287-8.

80 I. Philip (ed.), Journal of Sir Samuel Luke, I, Oxford Record Society (1947), p. 5.

${ }^{81}$ For cross-dressing Italian prostitutes during the medieval and early modern periods, see Bennett and McSheffrey, 'Early, erotic and alien', pp. 4-5, and, for the English tendency to connect
} 
The three pieces of evidence which we have considered so far make it hard to doubt that there were a number of cross-dressed women in the king's army, and that those women aroused strong moral condemnation: not only from Charles himself, but also from some of his opponents. Obviously, we cannot put too much weight on these fragmentary pieces of information, but they may have a bearing on the terrible atrocity which occurred in June 1645 when, after having defeated the royalists at the battle of Naseby, the soldiers of parliament's New Model Army turned on the king's female camp-followers, killing 100 of them and savagely mutilating many more. It has been suggested elsewhere that this massacre occurred partly because the parliamentarian soldiers believed the royalist women to be Irish; partly because they believed them to be 'whores'; and partly - perhaps - because they suspected that some of them were witches. ${ }^{82}$ Now it seems at least worth raising the possibility that the presence of a number of cross-dressed women among the king's campfollowers may also have played its part in stoking the soldiers' blood-lust, for, as we have seen, female transvestism and 'whoredom' were believed to be intimately associated at this time, while so, to a lesser degree, were female transvestism and witchcraft; Shakespeare's Joan of Arc provides an instructive example here. ${ }^{83}$

Yet, having said all of this, it would be wrong to conclude that, when it came to female cross-dressing, there was a water-tight attitudinal divide between 'repressive' Roundheads and 'relaxed' Cavaliers. Some in both camps may indeed have conformed to these respective stereotypes, but, as we have seen, the most virulent wartime condemnation of female cross-dressing may well have come from Charles I himself, while Oliver Cromwell, surprisingly enough, seems to have been 'amused rather than outraged', when he personally encountered a cross-dressed royalist woman ${ }^{84}$ This strange meeting occurred in March 1645, when forces under the command of the parliamentarian general Sir William Waller captured the royalist Lord Henry Percy and some ' 30 Horse' near Andover. ${ }^{85}$ Recalling the incident many years later, Waller recalled that he had ordered Cromwell, who was then acting as his second-incommand, to entertain the captives 'with some civility'. This the future

\footnotetext{
cross-dressing with 'foreignness', see ibid., pp. 14-16. For Dutch prostitutes who apparently donned male apparel for the purposes of 'erotic masquerade', see Dekker and Van De Pol, Female Transvestism, pp. 8, 39 (quotation) and 54.

82 Stoyle, 'Farndon Field', pp. 895-923.

${ }^{83}$ For the perceived connections between 'manly' women, transvestism and witchcraft, see Dekker and Van De Pol, Female Transvestism, pp. 43-4; Orgel, Impersonations, pp. 83, 110; and D. Underdown, A Freeborn People: Politics and the Nation in Seventeenth-Century England (Oxford, 1996), pp. 106-7. For Joan of Arc, see W. Shakespeare, The First Part of King Henry VI, esp. act 1, scene ii; act 1, scene v; and act 5, scene iii; and H. Castor, Joan of Arc: A History (London, 2014), pp. 90-2, 144, 174-5, 179, 208.

${ }^{84}$ Barratt, 'Secrets of the she-soldiers'.

${ }^{85}$ For Percy's capture near Andover on or around 9 March, see E.273 (6), A Diary, or an Exact Journal (London, 6-13 March 1645), un-paginated; E.273 (7), The Moderate Intelligencer (London, 6-13 March 1645), p. 313; E.273 (14), Mercurius Britanicus (London, 10-17 March 1645), pp. 597-8; and JHC, IV (1644-6), pp. 75-6. For Percy himself, see Newman, Royalist Officers, p. 293.
} 
Lord Protector had duly done, Waller goes on, and, while discoursing with the royalist prisoners, Cromwell's eye had been drawn to a particular individual:

a youth of so faire a countenance, that he doubted of his condition; and to confirm himself, willed him to sing, which he did with such a daintiness, that Cromwell scrupled not to say to Lord Piercy that, being a warriour, he did wisely to be accompanied by Amazons. On which that Lord, in some confusion, did acknowledge that she was a damsel. ${ }^{86}$

That Cromwell should have chosen to unmask this woman by asking her to sing not only suggests that he appreciated the humorous side of the situation, but also hints that he took it for granted that Percy's crossdressed companion was his mistress - and might therefore be assumed to boast the same accomplishments as those Italian 'curtisans, disguised in mens apparell', who habitually 's[a]ng and daunce[d] to their owne songes'. ${ }^{87}$

Cromwell's response to female transvestism in the enemy ranks was altogether more relaxed and worldly-wise than we might perhaps have expected, therefore, lending clear support to Patrick Little's recent argument that parliament's great captain was a man with a surprising propensity for jokes and jests. ${ }^{88}$ Yet this should not be taken to imply that either Cromwell or his godly confreres would have approved of Percy's decision to equip himself with a cross-dressed fille de joie. On the contrary, Waller specifically states that the unmasking of Percy's mistress 'afterwards gave cause for scoffe at the king's party, as that they were loose and wanton, and minded their pleasure, more than either their Country's service, or their Maister's good'. ${ }^{89}$ These words strongly suggest that however amused Cromwell may have been by Percy's embarrassment at the time - many in the Roundhead camp - including, it would seem, Waller himself - regarded the discovery that a prominent royalist had knowingly maintained a cross-dressed 'damsel' in his immediate entourage as irrefutable proof that their opponents were immoral, unsoldiery, unpatriotic, and, in the final analysis, more concerned with their own fleshly comforts than with the success of their cause. ${ }^{90}$ Certainly, Waller's testimony implies that cross-dressed courtesans were rarely to

\footnotetext{
${ }^{86}$ Hannah Cowley (ed.), The Poetry of Anna Matilda . . . To which are added Recollections . . . by General Sir William Waller (London, 1788), pp. 125-6.

87 T. Morley, A Plaine and Easie Introduction to Practicall Musicke (London, 1597), p. 181. For examples of 'disordered' women dancing in male attire in late medieval London and in early modern Exeter, see Bennett and McSheffrey, 'Early, erotic and alien', pp. 9-10; and M. Stoyle, From Deliverance to Destruction: Rebellion and Civil War in an English City (Exeter, 1996), p. 23.

88 P. Little, 'The Laughing Roundhead', History Today, 66/8 (2016), pp. 48-53.

89 Cowley, Poetry of Anna Matilda, p. 126.

90 In fairness to Percy, it must be stressed that he was not on active service at the time of his capture by Cromwell, as Waller's anecdote implies - let alone at the head of 'a raiding party', as one modern historian has claimed - but was rather on his way to voluntary exile in France, after having resigned all of his military commissions; see Carlton, Going to the Wars, p. 308 (quotation); Newman, Royalist Officers, p. 293; and JHC, IV, pp. 75-6. And while his cross-dressed female companion was clearly trying to pass herself off as a man - perhaps in order to spare Percy's blushes, perhaps in order to shield
} 
be met with in the armies of the parliament, and this, in turn, hints that - despite Charles I's avowed distaste for the 'prostitute impudency' of his soldiers' female consorts - the royalists, in fact, did far less than the parliamentarians did to regulate the morality of their 'camp women'.

Yet, even if the parliamentarian camp was an especially hostile environment for cross-dressed courtesans, this is not to say that it was an especially hostile environment for cross-dressed females per se. Because, intriguingly, the final piece of evidence which will be presented here reveals that, in certain circumstances, there were some on parliament's side who were prepared openly to celebrate the presence of cross-dressed women in their armies. In December 1645 a report appeared in the London diurnal The Scottish Dove which does not appear to have been noted by scholars before, and which therefore merits citing at some length. 'I have received knowledge of a discoverie in ... Evesham', the Dove's editor began:

which I will not omit to relate, for the strangenesse thereof... and it is thus: There was a young man (for so he was supposed to be) that was a foot-souldier in [the parliamentarian garrison of] Glocester about twelve moneths, and was very active and well exercised in Armes; he came afterward to Warwick, and was there entertained by a ... Captaine of Horse, to be ... a Trouper in his Troupe, and served him about a yeare ... and having obtained leave... to goe to see his friends in Shropshire, went to a taylor in Evesham ... and bespake a Petticoat and Wastcoat, desiring him to take measure by him; for (said he) it is for my sister, which is just of my stature every way: the Taylor being jealous [i.e. suspicious] that it was for himselfe to weare, told the Governour; and this young man was sent for, who was comely and of a faire complexion: and being examined, he sayd, he was indeed a female, and said that her selfe and three more sufficient men's daughters came out of Shropshire, when the King's forces commanded there, and to get away, came disguised in that manner, and resolved to serve in the Warre for the Cause of God... After shee was thus discovered, all those that had all this time knowne her carriage, witnessed, that shee would never come in bed with any ... but sometimes give six pence for a bed by her selfe; [or] if it could not be had, shee would sit up for many nights together: so that... [none], ever knew her to be of that Sex, which is great commendations to her, both for her zeale to the Cause of God, and for her modestie in carriage and behaviour. ${ }^{91}$

This report, short as it is, provides the most detailed account of female cross-dressing in Civil War armies to have emerged so far. We cannot be certain of its accuracy, of course - any more than we can be certain of the accuracy of the other contemporary reports concerning cross-dressed women which have already been discussed above. It is possible that the news which the Dove's editor relayed from Evesham was exaggerated in certain respects: conceivable, even, that the editor had simply invented the

\footnotetext{
herself from sexual harassment and innuendo during the course of her long journey - we cannot be certain that she was trying to pass herself off as a trooper.

${ }_{91}$ E.311 (4), The Scottish Dove (London, 27 Nov.-3 Dec. 1645), pp. 878-9. Sadly, no corroborative accounts of this incident have been found in other diurnals printed at around the same time.
} 
entire story in order to titillate and amuse his readers. Yet to assume that the report was a pure fabrication would almost certainly be going too far. For one thing, there is nothing inherently implausible about the account which appears in the Dove. It is delivered, throughout, in a sober, matterof-fact fashion, and while the twenty-first-century mind may boggle at the notion that a cross-dressing woman serving in a garrison town could keep her gender a secret for so long by the simple expedient of refusing to share a bed with her comrades, there are a number of well-documented cases from across early modern Europe of transvestite women who succeeded in passing themselves off as men for periods of anything up to ten years while engaged in military service: both on land and - more remarkably still - at sea. ${ }^{92}$ If the Dove's editor had cynically decided to concoct a story about the discovery of a cross-dressed female trooper, moreover, it seems far more likely that he would have chosen to set his tale in the royalist camp - thereby offering him the maximum opportunity to pour scorn on his opponents for the 'gender confusion' which they allegedly tolerated in their ranks - rather than setting his tale in the parliamentarian camp and thereby risking a similarly mocking response from the royalist polemicists.

It seems probable that the report which appeared in The Scottish Dove was grounded in truth, therefore, and that report contains several passages of absorbing interest: suggesting that it was possible for cross-dressed women to serve as foot-soldiers, as well as troopers, in Civil War armies for long periods of time without being discovered, for example, and implying that in 'England's Wars', as in other conflicts, the women who successfully disguised themselves as soldiers were usually very young. ${ }^{93}$ More important still, the report paints a strikingly different picture of wartime transvestism from that which appears in the other contemporary sources which have been examined so far. All of those sources - including Charles I's terse apostils - presented cross-dressed women in Civil War armies in a more or less erotic light: suggesting that they had donned male apparel chiefly in order to facilitate romantic or sexual liaisons with men. The parliamentarian 'she-trooper' who was apprehended at Evesham, by contrast - like her three shadowy fellow-countrywomen - is said to have donned male attire chiefly in order to preserve herself from her enemies and 'to serve in the Warre' for a cause in which she passionately believed. It was vital for the Dove's editor to present the unnamed woman at the centre of his account as a model of sexual propriety, of course, if he was to convince his readers that she was a 'virtuous virago': an exceptional woman in the mould of Joan of Arc or Mary Ambree, whose adoption of male attire should be regarded as an act of heroic religiosity

\footnotetext{
92 Dekker and Van de Pol, Female Transvestism, pp. 9-10, 19.

93 On the relative youth of most female cross-dressers, see ibid., pp. 13-14, 37 and 99; and J. Wheelwright, Amazons and Military Maids: Women who Dressed as Men in Pursuit of Life, Liberty and Happiness (London, 1989), p. 43. For a report concerning 'une jeune fille' of sixteen or seventeen who tried to pass through the parliamentarian court de garde at Hyde Park while wearing male clothes in 1644, and who was arrested on suspicion of being a spy, see E.1252(15), Le Mercure Anglois (London, 3-10 Oct. 1644), p. 63.
} 
and/or patriotism. ${ }^{94}$ Even so, his story strongly suggests that there were women on the battlefields of the 1640s who were there for their own reasons, and not as mere appendages - and that the stirring tale of 'the resolute lady' of Chester with which this article began may not have been so very unrepresentative of some women's real-life wartime experiences, after all. ${ }^{95}$

Why should we be interested in the women dressed as men who attended upon - and even, on occasion, served in - the armies of king and parliament? As the foregoing discussion has shown, the evidence relating to such individuals is pitifully scant: a fact which suggests that cross-dressed women may well have been a good deal less numerous in the royalist and parliamentarian ranks than some previous writers have implied. Yet, even if this is so, the activities of the women who donned masculine attire in order to march into the field during the 1640s should not be dismissed by historians as negligible or unimportant. The fact that Charles I himself chose to devote precious time - at the height of the summer campaigning season of 1643 - to devising regulations which insisted upon the severest punishment for any woman who dared to wear men's apparel 'in our Army' demonstrates just how much anxiety the practice of female cross-dressing in the field could arouse among some contemporaries. ${ }^{96}$ Similarly, the fact that both royalist and parliamentarian polemicists chose to publicize reports of the discovery of cross-dressed women in their own armies - even though those stories served no particular propagandist purpose - evidently reflects a keen appreciation on the pamphleteers' part that the 'strangeness' of that practice would arouse considerable interest among their readers. ${ }^{97}$ The trope of the cross-dressed female in the camp of Mars was clearly one which struck a deeply resonant chord in mid-seventeenth-century English society, in other words, and it is therefore a trope which should continue to matter to all of us who seek to understand that society today. Above all, though, the subject of female cross-dressing during the Civil War is surely worthy of detailed study in its own right because it helps to illuminate one small corner of a much larger story: that of how 'the crisis in English affairs' during the 1640s made space for some bold women fleetingly to test the boundaries of patriarchy. ${ }^{98}$

\footnotetext{
${ }^{94}$ For the concept of the 'virtuous virago', see N. Z. Davis, 'Women on top', in her Society and Culture in Early Modern France (Stanford, CA, 1975), pp. 124-51, at p. 129; and Wheelwright, Amazons, pp. $75-7$.

${ }_{95}$ For the broader argument that the stories told about cross-dressed women in ballads may well have quite accurately reflected the experiences of their real-life counterparts, see Dugaw, Warrior Women, pp. 122-31.

${ }_{96}$ BL, Harleian MS, 6804, fo. 76.

97 E.311 (4), p. 878.

98 B. Manning, 'Preface' to Higgins, 'Reaction of women', in Manning, Politics, Religion and the English Civil War, p. 178.
} 